\title{
Szkice
}

\section{Norwid, Baudelaire i reguły sztuki}

Magdalena Siwiec

TEKSTY DRUGIE 2020, NR 5, S. 121-137

DOI: 10.18318/td.2020.5.8 | ORCID: 0000-0001-5363-5294
Praca naukowa finansowana w ramach programu Ministra Nauki i Szkolnictwa Wyższego pod nazwą "Narodowy Program Rozwoju Humanistyki" w latach 2016-2021 (Nr $0046 / \mathrm{NPRH}_{4} / \mathrm{H}_{2} \mathrm{a} / 8_{3} / 2016$ ).
C yprian Norwid i Charles Baudelaire są poetami przełomu nowoczesności, nie tylko ze względu na czas i miejsce, w jakim przyszło im żyć i tworzyć, ale przede wszystkim na świadomość uczestnictwa we współczesnych im procesach społecznych i kulturowych ${ }^{1}$. Wyraźnie zaznacza się u nich silny wpływ paradygmatu romantycznego z przekonaniem o wybraństwie poety ${ }^{2}$. Przede wszystkim jednak obaj tworzą w momencie zmian społecznych w Europie, które Pierre Bourdieu zdiagnozował jako wyodrębnienie się w połowie XIX wieku autonomicznego pola literackiego stanowiącego jedno z pól

1 H.R. Jauss Przedmowa do pierwszego niemieckiego wydania "Vade-mecum" Cypriana Norwida, przeł. M. Kaczmarski, "Studia Norwidiana"1985, $1986 \mathrm{nr} 3 / 4$. Jauss pisze m.in. o krytycznym stosunku obu poetów do "utopii samoułudy ich czasów". O podstawach zestawienia Norwida i Baudelaire'a pisałam w artykule: Ze stygmatem romantyzmu. O Norwidzie i Baudelairze z perspektywy nowoczesności, "Teksty Drugie" 2014 nr 4, S. 196-214.

2 Zob. P. Bénichou Romanstismes français, 4 vol., Gallimard, Paris 2004.

\section{Magdalena Siwiec}

- dr hab., prof. UJ, kieruje Katedrą Komparatystyki Literackiej UJ. Ostatnio opublikowała książki: Romantyzm, czyli inter esse (2017, nagroda "Literatury na Świecie") oraz Romantyczne koncepcje poezji. Poeta i Muza - relacja w stanie kryzysu (Alfred de Musset i juliusz Słowacki) (2012), w roku 2019 pod jej redakcją ukazał się tom O Norwidzie komparatystycznie. Członkini redakcji „Ruchu Literackiego" oraz serii "Studia romantyczne" IBL PAN. 
produkcji kulturowej ${ }^{3}$. Norwid i Baudelaire w tym polu funkcjonują, współtworząc je i czyniąc ten proces przedmiotem refleksji. Baudelaire znajduje się w kręgu zainteresowań Bourdieu jako jeden z twórców, których prace sytuują się daleko od sztuki poddanej władzy lub rynkowi, podejmujących próbę stworzenia nowego nomosu. Jako prawodawca tego, co nowe, i kontestator porządku rynkowego twórczości artystycznej autor Paryskiego spleenu doskonale zna i opisuje ten porządek. Zna go dobrze i Norwid - twórca skądinąd konserwatywny, który pod wieloma względami jest jednak równie jak Baudelaire awangardowy, jeśli chodzi o tak istotne dla pola literackiego aspekty jak idea autonomii literatury (nawet jeśli rozumie ją inaczej niż francuski poeta), zwłaszcza zaś zakwestionowanie potrzeby jej łatwej zrozumiałości.

Współczesność XIX wieku, ,niegościnne, oślepiające doświadczenie epoki wielkiego przemysłu" ${ }^{\prime 4}$, to życie w szumie informacyjnym, w którym jedna wiadomość zasłania drugą i w którym te najistotniejsze gubią się, pozostają niezauważone, literatura zaś ma nadążać za tym szumem. Ów pęd wiąże się z tym, co autor Vade-mecum nazwał "panteizmem druku”, a Baudelaire „bezeceństwem druku, wielką przeszkodą w rozwoju Piękna” (SzR, 401)5. W Radach dla młodych literatów francuski poeta stwierdza: „dzisiaj trzeba dużo produkować; trzeba się więc spieszyć [...]" (SzRom, 48). Norwid zaś diagnozuje: „Żyjemy zaś (jeżeli się nie mylę?) w Epoce łatwego czytania rzeczy płodzonych szybko, ponętnych i głośnych" (PWVI, 500) .

3 Zob. P. Bourdieu Reguły sztuki. Geneza i struktura pola literackiego, przeł. A. Zawadzki, Universitas, Kraków 2001, s. 98.

W. Benjamin O kilku motywach u Baudelaire'a, w: tegoż Konstelacje. Wybór tekstów, przeł. A. Lipszyc, A. Wołkowicz, Wydawnictwo UJ, Kraków 2012, s. 265. O Norwidzie w kontekście myśli Benjamina zob.: K. Trybuś Benjamin komentatorem Norwida, w: WokółPasaży Waltera Benjami$n a$, red. P. Śniedziewski, K. Trybuś, M. Wilczyński, Wydawnictwo UAM, Poznań 2009; M. Kuziak Norwidowska alegoria (przez pryzmat refleksji Waltera Benjamina) w: Symbol w dziele Cypriana Norwida, red. W. Rzońca, Wydawnictwa UW, Warszawa 2011; tegoż Norwid i pejzażnowoczesności. Wokół Paryża poety, ,"Studia Norwidiana" 2014 nr 32.

5 Wszystkie cytaty z dzieł Baudelaire'a prozą za wydaniem gdańskim. Dalej stosuję skróty: SzRom - Ch. Baudelaire Sztuka romantyczna, wstęp A. Kijowski, przeł. E. Burska, S. Cichowicz, A. Kijowski, M. Sawiczewska, T. Swoboda, słowo/obraz terytoria, Gdańsk 2003; RE Ch. Baudelaire Rozmaitości estetyczne, wstęp i przeł. J. Guze, słowo/obraz terytoria, Gdańsk 2000; SzR - Ch. Baudelaire Sztuczne raje, wstęp i przeł. R. Engelking, słowo/obraz terytoria, Gdańsk 2009; L - Ch. Baudelaire Listy. Biedna Belgia! Teatr, przeł. R. Engelking, słowo/obraz terytoria, Gdańsk 2015. Po skrócie tytułu i przecinku podaję numer strony.

6 Wszystkie cytaty z dzieł Norwida za wydaniem: K. Norwid Pisma wszystkie, red. J.W. Gomulicki, PIW, Warszawa 1971-1976. Dalej podaję w nawiasie skrót PW, numer tomu i numer strony. 
Zmiana sytuacji twórcy wiąże się przede wszystkim z tym, że sztuka staje się towarem. Nowoczesny artysta, dla którego inne źródła dochodu są ograniczone, staje przed alternatywą: bieda lub poddanie się powszechnym $\mathrm{i}-\mathrm{w}$ przypadku poetów mocnych - nieakceptowanym przez siebie gustom, ujmując rzecz krótko - sprzedanie się. O tej chwiejności pozycji ekonomicznej inteligencji wchodzącej na rynek literacki jako bohema pisze Walter Benjamin? . Tak wkraczają nań i Baudelaire, członek paryskiej bohemy, i Norwid związany z kręgiem Cyganerii Warszawskiej, która stanowi jedno z pierwszych w Polsce świadectw buntu wobec nowoczesnego rynku czytelniczego $^{8}$. Norwid wokół praw rynkowych rządzących sztuką zbudował nowelę Ad leones, świetnie zinterpretowaną z tej perspektywy przez Zofię Stefanowską?. Analizę tych praw znajdziemy także w Aktorze, Próbach czy Rzeczy o wolności stowa. Kiedy z kolei Baudelaire formułuje Rady dla mtodych literatów, wspomina o "rozmaitych pracowniach naszej artystycznej fabryki” (RE, 205) czy w relacji z Wystawy Powszechnej 1855 roku pisze o poezji jako lokacie (SzRom, 49), używa określeń ze sfery ekonomicznej, zaświadczając tym samym o istnieniu rynku literackiego. Poezja jest zawodem, a sprzedaż wynika z przymusu zarabiania na życie. Ta diagnoza nie oznacza jednak akceptacji stanu rzeczy, zarówno u Norwida, jak i u Baudelaire'a wyraźny jest ton krytyczny, często także ironiczny. To ten ton właśnie pozwala Antoine’owi Compagnionowi na określenie pisarzy takich jak Baudelaire mianem antimodernes ${ }^{\mathbf{1 0}}$.

7 Zob. W. Benjamin Paryż - stolica dziewiętnastego wieku, w: tegoż Twórca jako wytwórca. Eseje i rozprawy, przeł. R. Reszke, KR, Warszawa 2011, s. 328.

8 Zob. tamże, s. 328-329; Z. Stefanowska Norwid - Pisarz wieku kupieckiego i przemysłowego, w: tejże Strona romantyków. Studia o Norwidzie, TN KUL, Lublin 1993, s. 19-20; P. Bourdieu Reguły sztuki, s. 87-92.

9 Zob. Z. Stefanowska Pisarz wieku kupieckiego..., s. 19-21. Stefanowska podkreśla, ambiwalentny stosunek poety do postępu, w którym widzi on także szansę dla rozwoju Polski (s. 27-30, 4145). Wiąże się on, zdaniem badaczki, z nakładaniem się na siebie u Norwida dwóch zespołów przekonań: związanym z misją poety narodowego i pojęciem pisarza cywilizacji industrialnej o mentalności zawodowego literata (s. 15, 46). Od strony Baudelaire'a zob.: Zob. G. Froidevaux Baudelaire face à son époque, "Littérature” No. 63: "Communiquer: représenter" octobre 1986; D. Combe L'esthétique kantienne et la genèse de l'Art Pure, w: Baudealire et le romantisme Modernité et romantisme, textes réunis par I. Bour, E. Dayre, P. Née, Honoré Champion, Paris 2001; G. Robb La poésie de Baudelaire et la poésie francaise 1838-1852, Aubier, Paris 1993; A.-M. Amiot Les fleurs du mal. Baudelaire. Un romantisme fondateur de la modernité poétique, Ellipses, Paris 2002.

10 Zob. A. Compagnon Les antimodernes: De Joseph de Maistre à Roland Barthes, Gallimard, Paris 2005. 
Nie zmienia to faktu, że sporo energii obaj twórcy wkładają w zmagania z wydawcami, walcząc (z większym lub mniejszym sukcesem) i o sam druk, i o jego formę, i o honoraria. Znaczące jest, jak wiele miejsca zajmują w ich korespondencji kalkulacje, co się sprzeda i za ile. By zorientować się w spekulacjach pisarzy na temat potencjalnych dochodów, wystarczy przeczytać listy Norwida do Józefa Bohdana Zaleskiego czy Zygmunta Krasińskiego na temat teki ilustracji do Bogurodzicy ${ }^{11}$, w sprawie sprzedaży Quidama, cen wejściówek na Norwidowe odczyty, artykuł o Olizarowskim zawierający świadectwo prób spieniężenia rękopisów przyjaciela czy uwagi Baudelaire’a związane z publikacją eseju o Guysie. Myślenie o własnym dziele jako towarze, za który oczekuje się zapłaty i który ma decydować o warunkach życiowych artysty, wciąż powraca w korespondencji poetów, ujawniając raz po raz niejednoznaczność ich stosunku do tych kwestii.

Norwid jest przekonany, że druk bez wynagrodzenia czy wręcz finansowanie go z kieszeni autora to obniżanie rangi literatury. W tym kontekście szczególnie ważne są listy poety, w których wielokrotnie podkreśla, że publikowanie przez twórcę za własne pieniądze i rezygnacja z honorarium to procedura niemoralna. Wyznaje, krytykując szczególnie polski rynek wydawniczy: „Jak żyję, nic nie publikowałem moim kosztem, dlatego że to jest źle [...]” (PW IX, 330). Gdzie indziej pisze: „To w szys tko [finansowanie własnychpublikacji-M.S.] jest radykalnie złe i ja nic nie płacę, owszem, jeśli mnie nie płacą, to widać, że ktoś z nas nie wart, a lbo pis arz, albo publicznoś ć" (PW IX, 218). Baudelaire w $Z a-$ cnych dramatach i powieściach prawo rynku (np. zarabianie na pisaniu sztuk) wynosi ponad nagrody państwowe. Pierre'a Duponta natomiast chwali za to, że „zmusił Muzę do odegrania w swym życiu roli użytecznej, czynnej” (SzRom, 6o) i wykupił się poezją z niewolnictwa (pracy w banku). Zdobyty dzięki pisarstwu pieniądz może być zatem drogą do wolności. W każdym razie twórców łączy myślenie o uprawianiu sztuki zawodowo. Jak jednak zaznaczyłam, z myśleniem tym wiąże się bunt, niechęć do podporządkowania się i pragnienie dyktowania społeczeństwu własnych koncepcji, narzucania własnej wizji świata, która zasadniczo rozmija się z czytelniczymi oczekiwaniami. Norwid i Baudelaire wpisują się w heroiczną walkę o niezależność

11 Z. Stefanowska zwraca uwagę na różnicę w traktowaniu przez Norwida pracy rzemieślniczej plastycznej i twórczej - poetyckiej. Pisze także o jednoczesnej potrzebie uznania przez nową, bo anonimową, publiczność i pogardzie dla popularności. Zob. Z. Stefanowska Pisarz wieku kupieckiego..., s. 34-36. 
wobec represji, która w tym czasie nabiera charakteru "podporządkowania strukturalnego"12. Istotny jest przy tym fakt, że obaj stoją między sprzecznymi postawami: zawodowstwem a misyjnością poezji. Bycie pisarzem jest przecież misją (to dziedzictwo - szczególnie polskiego - romantyzmu), co zasadniczo wyklucza pisanie dla pieniędzy. To jeden z paradoksów skomplikowanego stosunku obu poetów do przemian. Chodzi zresztą nie tylko o ciążenie modelu romantycznego, ale także o nowe wyzwania - tworzenie pola literackiego. Wiążą się one ze zjawiskiem, które Bourdieu nazywa „ekonomią na opak" - kwestionowaniem praw rynku w imię tryumfu symbolicznego tożsamego z porażką ekonomiczną ${ }^{13}$.

Romantyczny motyw wyobcowania i niezrozumienia poety przez odbiorców nabiera w nowej rzeczywistości dodatkowych znaczeń ${ }^{14}$. Wiąże się bowiem z ekonomicznym uzależnieniem poety od publiczności, której oczekiwania odczuwane są jako sprzeczne z intencjami poety. Tu pojawia się kolejny problem związany z pisarstwem zawodowym - sprzedaje się to, co publiczność chce kupić, a chce kupić to, co jej się podoba i co zazwyczaj ma charakter rozrywki i wymaga obniżenia jakości dzieł. Obaj twórcy mierzą się z procesem komercjalizacji literatury, w którym Muza musi być „Muzą przedajną”, by przeżyć, a arcydzielność „zniewoli do pługa / Świat i nowy duch kupiecki" (PW I, 64). Elitarność sztuki zostaje wyparta przez jej powszechność, jakość przez ilość, a ci twórcy, którzy - jak Norwid i Baudelaire, tego nie akceptują - próbują tworzyć nowe zasady, podważające ten stan rzeczy i pisać dla odbiorcy, którego sami zaprojektują, a który sytuuje się na antypodach publiczności ${ }^{15}$. Obaj też z negatywnie wartościowanej sprzedaży sztuki czynią przedmiot swych utworów artystycznych. Warto pamiętać w tym kontekście i o wierszach takich jak Na zgon Poezji („Umarła ona [Poezja] na ciężką chorobę, / Która się zowie: pi en iąd z i bruli o ny" PW II, 200),

12 P. Bourdieu Reguły sztuki, s. 79-80.

13 Zob. tamże, s. 129-130, 144-145.

14 O nowoczesnym wyobcowaniu u Baudelaire'a zob. np. J.E. Jackson Baudelaire sans fin. Essais sur "Fleurs du Mal", Corti, Paris 2005; u Norwida - np. M. Kuziak Norwidowskie "przedstawienie" W"Vade-mecum", w: Liryka Cypriana Norwida, red. P. Chlebowski, W. Toruń, TN KUL, Lublin 2003; R. Fieguth Poezja w fazie krytycznej. Cykl wierszy Cypriana Norwida "Vade-mecum", w: tegoż Poezja w fazie krytycznej i inne studia z literatury polskiej, przeł. K. Chmielewska, Świat Literacki, Izabelin 2000, s. 76-180.

15 Na temat Norwidowego postulatu świadomego uczestnictwa w kulturze oraz projektowanego odbiorcy zob. Z. Łapiński Norwid, Znak, Kraków 1984, s. 37-38,57, 68-72, 78, 105-145. 
i o pracach plastycznych Norwida ilustrujących sytuację współczesnego artysty - zwłaszcza o Le musicien inutile, który to rysunek Alicja Lisiecka uznała za emblematyczny dla sytuacji Norwida na emigracji oraz o - ważniejszym z mojej perspektywy - Pegazie prowadzonym na sprzedaż ${ }^{16}$. Baudelaire podejmuje ten temat w poezji - myślę zwłaszcza o sonecie o znaczącym tytule $L a$ Muse vénale [Muza przedajna]:

II te faut, pour gagner ton pain de chaque soir,

Comme un enfant de chœur, jouer de l'encensoir,

Chanter des Te Deum auxquels tu ne crois guère [...]

Musisz, aby zarobić na kawałek chleba,

Niby chłopiec kościelny kadzić, gdzie potrzeba,

Bez wiary śpiewać hymny jak szpak wyuczony $[\ldots]^{17}$

Prawo rynku, które wymusza na poecie dostosowanie się do niskich gustów, sprzeczne jest w wierszu ze wzniosłymi ideami. Sama Muza nabiera charakteru ambiwalentnego - jest z jednej strony wytworem wyobraźni poety i jej alegorią, z drugiej - metonimią, chodzi bowiem nie tyle o pieśni i błazenady samej Muzy, ile o twórczość zgodną z wymogami publiczności. Motyw sprzedaży Muzy określający stan współczesnej kultury powraca także w innych tekstach Baudelaire'a. W artykule o Petrusie Borelu krytyk docenia tego niedoskonałego pod wieloma względami pisarza jako twórcę oryginalnego i kochającego literaturę, co wyróżnia go na tle dominującego typu literata. Jak bowiem pisze Baudelaire: „dzisiaj jesteśmy przytłoczeni masą pisarzy zręcznych i gładkich, którzy gotowi są sprzedać Muzę za rolę garncarzową" (SzRom, 163). Fragment ten stanowi niejako negatyw przywołanej wcześniej wypowiedzi o Duponcie, w której też pojawia się motyw sprzedaży Muzy, tyle że tam nabiera on wymiaru pozytywnego, natomiast tutaj wydźwięk jest zdecydowanie pejoratywny. Współczesny artysta staje się profanatorem, Judaszem sprzedającym to, co stanowi wartość najwyższą - w bardzo mocnym porównaniu Baudelaire'a pobrzmiewa zarówno sakralizacja sztuki, jak i krytyczna samoocena twórcy.

Zob. A. Lisiecka „Legenda wieków” Norwida i legenda Parnasu, "Pamiętnik Literacki” 1968 z. 59/4.

17 Ch. Baudelaire La Muse malade (Muza chora), przeł. J. Opęchowski, w: tegoż Kwiaty zła. Les Fleurs du mal, oprac. M. Leśniewska, J. Brzozowski, Wydawnictwo Literackie, Kraków 1994, s. 32-33. 
Obaj poeci odwołują się też do motywu tonowania, hamowania łez, smutku, wymuszonego ze względu na gusty odbiorców. Krytyka radzi w wierszu Norwida:

Płacz!!...

- lecz, jeżeli ból jest gorzki? ...

- niemniej

W książce on może brzmieć lżej i przyjemniej,

Rytm powodując dla słuchaczów miły [...] (PW II, 141)

Także Muza Baudelaire’a musi ukrywać płacz:

$\mathrm{Ou}$, saltimbanque à jeun, étaler tes appas

Et ton rire trempé de pleurs qu'on ne voit pas,

Pour faire épanouir la rate du vulgaire.

Lub jak błazen wykrzywiać na głodno swe ciało

Łzy łykając, udawać wesołość zuchwałą,

By się zatrzęsły śmiechem pospólstwa śledziony. ${ }^{18}$

Sprawa stosunku poetów do wynagrodzenia daleka jest od oczywistości, a splot sprzecznych dążeń i nastrojów odcisnął swe piętno w ich pismach. Trochę światła na te paradoksy rzuca list Norwida do Mariana Sokołowskiego z 15 września 1875 roku. Poeta pokazuje w nim sprzedaż książki jako wymianę ekonomiczną i zarazem ewangeliczną - z zachowaniem godności twórcy i kupującego, który płacąc, oddaje równoważność pracy włożonej w dzieło, oddaje zatem cząstkę siebie. To w tym sensie pieniądz może być,,wstępem do książki”:

Każdy oświecony obywatel wie dziś, że nie idzie o to, aby książka była tanią - wcale nie o to idzie, ale o to:

aby pieniądz, który jest zapłaconym za książkę, kosztował pierwej tyle trudu, ile należało go osobiście ponieść, aby książkę potem ocenić. Idzie o to, aby pieniądz był niejako w s tę p e m do ks iążki! (PW IX, 311)

Istotne w tym kontekście wydaje się to, jak Baudelaire pisze o relacji sztuki i prostytucji. Stwierdzając: „Czym jest sztuka? Prostytucją” (SzR, 341),

18 Ch. Baudelaire La Muse malade (Muza chora), s. 32-33. 
dokonuje on odwrócenia sensów - prostytucja przestaje być figurą sztuki, która się sprzedaje (choć i do tego znaczenia poeta się odwołuje). Przeciwnie - nabiera sensu pozytywnego, oznacza powszechne i szlachetne w swej istocie dzielenie się sobą z innymi, bo „Wielbić to poświęcać się i prostytuować. / Zatem wszelka miłość jest prostytucją" (SzR, 386) ${ }^{19}$. Poeta zatem świadomie włącza się w los prostytutki, oddając w publiczny obrót swoje dzieła na zasadzie komunii (zatem także i Baudelaire - choć inaczej niż Norwid - wprowadza w to porównanie wymiar ewangeliczny). To przeformułowanie jest oczywiście jedną z prowokacji artysty godzącego w ustalone sądy. Przeciwieństwem afirmowanej postawy dzielenia się jest zawłaszczenie (SzR, 341), którego synonimem będzie dla Baudelaire'a (zob. np. RE, 208) - tak samo zresztą jak dla Norwida w Adleones - amerykanizacja jako figura kapitalizmu. Jak „kapitalizacja” w noweli Norwida świadczy o degrengoladzie, tak dla Baudealire'a „Handel jest w swej istocie czymś s z a t a ń s k i m” (SzR, 398).

Oczywiście poza prawem rynku nowym polem literackim rządzi przynależność do elitarnej grupy. Także i ten aspekt znajduje się w obrębie refleksji obu poetów. Baudelaire analizuje związaną z niewymiernością literatury sytuację twórcy, który chce wprawdzie zarabiać jak najwięcej, skłonny jest jednak do rezygnacji z wysokich zarobków, po to tylko, by należeć do grona pisarzy postrzeganych jako elitarna wspólnota (SzRom, 46). Poeta demonstruje względność i idącą za tym chwiejność pozycji literata ${ }^{20}$. Stwierdza: „Nagroda pisarzy znajduje się w kasach księgarskich i polega na szacunku, jaki mają dla nich ci, którzy są im równi" (SzRom, 73). Widać tu owo podwójne wartościowanie: zarobki i uznanie wspólnoty artystycznej - zjednej strony mają świadczyć o niezależności, z drugiej - sprzedaż zależy od gustów publiczności.

Fenomenem czasów związanym z polem władzy jest rozwój dziennikarstwa i powieści - form systemowo preferowanych. Obaj twórcy diagnozują zalew „jaskrawych i przelotnych” (PW VI, 500) książek, zwłaszcza powieści, które Baudelaire nazwał „gatunkiem bękarcim, którego dziedzina jest naprawdę nieograniczona” (SzRom, 127) a o których Norwid pisze: „Lat temu

\footnotetext{
cywilizacyjne. Podstawowym wyznacznikiem kryzysu literatury jest według badacza jej utekstowienie”, przejście od mowy do pisma - tj. komercyjnej publikacji książkowej. To zaburzenie prowadzić może do nowatorskich rozwiązań. Zob. A. Vaillant La crise de la littérature. Romantisme et modernité, UGA Éditions, Grenoble 2005.

O chwiejności, zawieszeniu poety między własnymi celami a oczekiwaniami publiczności pisze A. Vaillant, który podkreśla uwikłania literatury tego okresu w realia polityczne, ekonomiczne,
} 
kilkaset kto pomyślił, że romans rozszerzy się na taką rozległość estetyczną, iź świat przykryje bibułą swoją" (PW VI, 651; zob. też PW VI, 418 i PW III, 280), jak i czasopism. To one przyczyniają się do pisania na akord, tworzenia powieści w odcinkach, felietonów ${ }^{21}$. Norwid wypowiada się z niechęcią o popularności krótkich form felietonowych i łatwych powieści w Polsce: „[...] przeważny jest rozwój dzi ennikarstwa i powieści. Z tych zaś pierwsze ma za wyraźną - lubo bezwyraźnie praktykowaną zasadę uważać jako węgielny warunek zad ow ol eni e publiczności, tudzież życzy sobie rozwojów k r ó t k i c h i przeto zarazem silnie streszczonych i jednakże nieciężkich" (PWVI, 652). Warto wspomnieć także choćby O felietonie felieton przedstawiający tę formę dziennikarską jako opartą na nieprawdzie i pasożytniczą czy Maskę-Feuilleton - postać w Tyrteju (za kulisami), którą „uciąża” każda nowinka. Baudelaire (sam felietonista!) z pogardą pisze o popularnych „zacnych powieściach i dramatach”, a także o „podrzędnych dziennikarzach [którzy, krytykując Wagnera - przyp. M.S.] prezentowali swoje zawodowe błazeństwa" (SzRom, 371). Francuski twórca demaskuje także hipokryzję czasopism, które pod hasłami pochwały postępu cywilizacyjnego propagują zepsucie - w Racach wspomina o nich z odrazą, nazywając je „kolekcją okropności" (SzR, 400). Nie bez powodu w słynnym śnie o muzeum-burdelu opisanym w liście do Charles'a Asselineau pojawia się fantazja o „Le Siècle" jako dzienniku „tak głupim, by otworzyć dom publiczny połączony z czymś w rodzaju muzeum medycyny" (to połączenie spekulacji nierządem i maniakalnej wiary w postęp), (L, 204). Do mechanizmów opisywanych przez pisarzy wpływających na pole literackie należy reklama książek przygotowywana przez krytykę, która choć częstokroć niekompetentna, kształtuje gusta i - co za tym idzie - sprzedaż. Norwid wielokrotnie kpi z „odkryć” czasopiśmienniczej krytyki, świetnym przykładem jest autoreferencyjna Krytyka (wyjęta z czasopismu), a także Dwie powieści czy zakończenie Stygmatu. Symptomatyczny wydaje się także tytuł anegdotycznego artykułu Baudelaire’a Jak płacić dtugi, gdy jest się geniuszem. Odnosi się on do Balzaca, a odsłania kulisy wyrobniczej pracy pisarza zawodowego, tworzącego na akord dla czasopism i uciekającego się do kupowania tekstów u podwykonawców (co stawia pod znakiem zapytania kwestię autorstwa). Esej sam jest zresztą napisany dla gazet - został opublikowany anonimowo w „Le Corsaire-Satan”, a potem przedrukowany

21 Są to jak pisze Bourdieu formy promowane przez ówczesne władze, zob. P. Bourdieu Reguły sztuki, s. 89, 140-141. Na temat znaczenia prasy i jej polityczności oraz roli w zacieraniu granic między autorem a czytelnikiem zob. W. Benjamin Paryż-stolica..., s. 12-13. 
w „Echu”, już z podpisem. Jak komentarz do opisanej przez Baudelaire'a sytuacji francuskich autorów periodyków brzmi Norwidowa ocena dziennikarstwa "które do zupełnej płaszczyzny i równej niziny stylu do[szło] - tak że pytasz się czasem, czemu się jeszcze ci ludzi e podpisu ją?! - kiedy to różnica tylko łokci tegoż samego materiału..." (PW VI, 655). Spojrzenie na francuską prasę dowodzi, że właśnie często się nie podpisują lub podpisują się nazwiskami kolegów, za których wykonują pracę (jak Nerval i Gautier, którzy wzajemnie świadczą sobie takie przyjacielskie usługi). Baudelaire stale pisze felietony z pełną świadomością charakteru tej pracy. W prywatnych listach wyznaje, że ucieka się do kłamstwa, wydając publicznie sądy (np. o Nędznikach Hugo) odmienne od tych, z którymi by się identyfikował. Jest to i działanie pod publikę, i swoista dyplomacja, która poniekąd kłóci sięz wizerunkiem poety bezkompromisowego i prowokacyjnego, jak przedstawia go Bourdieu. Norwid ubolewa nad opłakanym stanem dziennikarstwa polskiego, bowiem my „zamiast dziennikarstwa mamy mechanikę dziennikarstwa o d obcy ch w zi ę tą i coś, co we mgłach emb-brionu jeszcze spoczywa" (PWVI, 438). Jednocześnie w korespondencji prywatnej i w Listach o Emigracji poeta pisze o społecznych powinnościach czasopism, uznając ich znaczenie dla kształtowania opinii publicznej (PW VII, 19). Negatywna ocena czasopiśmiennictwa nie zmienia faktu, że obaj pisarze fenomen współczesnego dziennikarstwa doceniają, widząc zarówno jego wady, jak i zalety - możliwości, jakie daje. Sami tworzą - każdy na swój sposób - nowy rodzaj krytyki literackiej i krytyki sztuki (relacje z Salonów), mam tu na myśli zwłaszcza wykłady o Słowackim z jednej strony, a analizę Pani Bovary oraz Rozważania o niektórych moich wspótczesnych z drugiej.

W wyłanianiu się pola literackiego ważną rolę odgrywa salon - zwłaszcza mieszczański, opisywany przez Bourdieu jako instytucja kreująca gusty, przeciw której występują pisarze tworzący własne reguły sztuki ${ }^{22}$. Francuski poeta wprowadza do jednego ze swych esejów opis owego salonu, w którym dokonuje się arbitralnych i niesprawiedliwych ocen artystów i który ci ostatni muszą odczuwać jako więzienie:

Przyjmuję, że jesteś uwięzi ony w mieszczańskim salonie, że pijesz kawę po obiedzie z panem domu, z panią i panienkami. Nienawistny i śmieszny żargon, od którego pióro musi się uwolnić, tak jak pisarz musi unikać takich denerwujących wizyt! Wkrótce będzie 
się mówić o muzyce, może o malarstwie, a na pewno o literaturze. (SzRom, 112-113)

Salon to miejsce, w którym sztuka jest zdegradowana do przyjemnego tematu podejmowanego przy kawie, ułatwiającego trawienie po obiedzie. Fragment ten przypomina opisy salonów Norwida w tak wielu utworach (np. Ostatni-despotyzm, Aktor, Pierścień wielkiej damy, Stygmat) i w epistolarnej korespondencji przedstawianych jako miejsce obłudy, hołdowania przelotnym modom, pustoty, ignorowania spraw prawdziwie ważnych, konwenansu, płynności i grzeczności, „salonowych grzechów i gawędek” (PW VIII, 210). I choć Norwid myśli raczej o salonach arystokratycznych niż burżuazyjnych i raczej polskich niż francuskich, charakterystyka tej instytucji jest podobna jak u Baudelaire'a. Autor Paryskiego spleenu pisze o „nienawistnym i śmiesznym żargonie" i o obiegowych sądach na temat sztuki, niedoceniających wielkich twórców (SzRom, 112-113). Norwid z kolei przekonuje, że w dzisiejszym salonie „nim się kilka słów starannie wyrzecze, wejdą figury i przerwą, i kiwać się do siebie zaczną, bzdurząc serio o faribolach [...]" (PW IX, 134). Rozmowa salonowa i u Baudelaire'a, i u Norwida jawi się jako pusta, uwikłana w konwenanse, pełna hipokryzji i omijająca kwestie najistotniejsze. Owa pozorność salonowego dialogu została wyeksponowana także w A Dorio ad Phrygium:

Salony ledwo że modą żywe,

A udawającymi zdań zamianę

Monologami są rozmowy!... (PW III, 322)

Skargi Norwida korespondują z krytyką Baudelaire'a, ale polski poeta pisze także o potrzebie salonu jako instytucji. Obaj pisarze bowiem są świadomi jego znaczenia, choć wykraczają poza wąskie zakreślane przezeń ramy. W liście do Delfiny Potockiej Norwid pisze o salonie w kontekście potrzeby „od-publicznienia języka", znalezienia przestrzeni poza przestrzenią oficjalną, a jednak instytucjonalnie określoną (PW VIII, 330). Te próby Norwida potwierdzają przedstawioną przez Bourdieu prezentację salonów jako łączników między polami, przestrzeni negocjacji wpływów. Także i w tej sferze widoczna jest jednoczesna przynależność i transgresywność określająca stosunek pisarzy do współczesnych im zjawisk.

Obaj poeci zostali w pewnym sensie odrzuceni przez pole władzy: Baudelaire poddany procesowi, który przegrał, Norwid skazany przez środowisko emigracyjne na ostracyzm. W obu przypadkach można mówić o różnych 
rodzajach cenzury. Bourdieu prezentuje sytuację Baudelaire'a w sposób zaskakująco przystający do zmagań Norwida. Pisze mianowicie o dwojakim źródle - zewnętrznym i wewnętrznym - poczucia upokorzenia i w związku z tym ambiwalentnym stosunku do samego siebie, poety postrzegającego się z jednej strony jako artystę nieudacznika z drugiej - jako artystę przeklętego ${ }^{23}$. Potrzeba wyższości splata się w obu przypadkach z ogromną potrzebą instytucjonalnego docenienia. I u Baudelaire'a, i u Norwida można zaobserwować z jednej strony odrzucenie powszechnie obowiązujących gustów, z drugiej - domaganie się publicznego uznania; obaj jednocześnie odrzucają reguły i chcą się w nie wpisywać (ale na własnych zasadach).

Ważny z tego punktu widzenia staje się problem nagród i odznaczeń, o których Bourdieu pisze jako jednym z narzędzi władzy. Norwid wyśmiewa się z orderów i ludzi „orderowych” - np. w Tajemnicy czy w Szczęściu, gdzie poza ironicznym pytaniem - „Bo na cóż? zdadzą się wstążki - mężczyźnie!...” (PW II, 29), pojawia się umieszczona w przypisie wyraźna krytyka odznaczeń, stanowiąca zrazem diagnozę socjologiczną: „Dekoracje zdają się być zawsze dowodem braku albo fałszu jawności w społeczeństwie;ztej to przyczyny najmniej ich w Anglii widać, a najwięcej w Rosji” (PW II, 29). Zatraciły one już charakter nagrody za autentyczne zasługi na tyle, że stają się dla Norwida świadectwem hipokryzji. Baudelaire ma na ten temat takie samo zdanie: „Nagrody przynoszą nieszczęście. Nagrody akademickie, nagrody za cnotę, ordery, wszystkie te wynalazki szatana sprzyjają hipokryzji i mrożą żywiołowe porywy swobodnego serca. [...] W nagrodzie oficjalnej jest coś, co obraża człowieka i ludzkość, rozdrażnia wstydliwość, którą odznacza się cnota" (SzRom, 73). Zarówno w cytowanym tu eseju o literaturze cnotliwej, która nie ma zdaniem poety nic wspólnego z prawdziwą moralnością, jak i potem, w Moim obnażonym sercu Baudelaire podkreśla niestosowność wręczania nagród związaną z poczuciem wyższości tego, kto ją wręcza i kto przypisuje sobie symboliczną władzę: „Przyjmując order, uznajesz, że państwo czy monarcha ma prawo oceniać cię, wyróżniać etc." (SzR, 371). Rację ma zatem Bourdieu, twierdząc, że francuski pisarz dostrzega mechanizmy władzy i walczy z narzuconym przez nią porządkiem. Podobnie myśli o orderach Norwid.

Oprócz odznaczeń istotnym narzędziem II Cesarstwa, pozwalającym na zapanowanie nad sferą nauki i sztuki jest Akademia, a także intratne posady i stypendia. Akademia ma znaczenie przede wszystkim dla intelektualistów francuskich, ale jej idea jest znana i komentowana także przez polską 
emigrację. Norwid pisze satyryczny wiersz Posiedzenie przedstawiający członków Akademii jako debatujących wyłącznie nad listą obecności, podczas gdy inni faktycznie dokonują ważnych odkryć i zmieniają świat. W Rzeczy o wolności stowa „Akademii członek, / D z i e n n i ka rz, o p o w i eś c i a r z lub n a d z o r c a c z c i o n e k" (PW III, 596) stanowią grupę tych, którzy znaczenia słowa nie rozumieją, choć nim się zajmują zawodowo, ich związek z rynkiem jest dla Norwida niezaprzeczalny. Jałowość i bezużyteczność akademickich dyskusji Norwid podkreśla także w innych wypowiedziach (PWVI, 277). Baudelaire natomiast krytykuje Akademię jeszcze bardziej zajadle, nie tylko jako symbol władzy; znając jej członków, tym łatwiej ich demaskuje. Akademia to, jego zdaniem, instytucja obłudna, nepotyczna, która chce „przekształcić sanktuarium muz w parlament malkontentów”, w której „podkrada się” fotele (SzRom, 194) - te opinie powtarza poeta za Sainte-Beuve'em, którego artykuł poddaje krytyce, jednak pozostają one w mocy.

I tu pojawia się druga strona tej „orderowej” historii. Obaj pisarze na różne sposoby negocjują bowiem z polem władzy. Baudelaire, mocno krytykujący wszelkie instytucjonalne i zarazem protekcjonalne wyróżnienia, podejmuje próbę dostania się do Akademii pod koniec 1861 roku. Jest to gest niejednoznaczny i z tego względu skrajnie różnie interpretowany: bądź jako wyraz autentycznej chęci bycia przyjętym do prestiżowej grupy, bądź jako prowokacja ${ }^{24}$. Autor Kwiatów zła - tak negatywnie wypowiadający się o orderach domaga się odznaczenia Legii Honorowej, a także posady dyrektora teatru. Zdaniem Bourdieu Baudelaire zmusza w ten sposób instytucję, by objawiła swą niezdolność do uznania go, a jednocześnie zabiega o to uznanie. Podobną sprzeczność można zauważyć w postawie Norwida, który także pragnie docenienia przez instytucję. Mimo przywoływanej wyżej krytyki odznaczeń widzi potrzebę tego rodzaju znaku wdzięczności społeczeństwa. Zasadniczo (mimo zastrzeżeń dotyczących spóźnionego gestu) popiera złożenie wyrazu uznania Matejce (PWX, 21), a podobałoby mu się także wręczenie medalu Sznajnosze jako gest „społeczeństwa przyzwoitości” (PW VI, 501). Oczywiście dla Norwida w sytuacji nieistnienia polskiej państwowości instytucje stanowiące protezę działań obywatelskich będą mieć inne znaczenie niż dla Francuza

24 Prowokacją jest ten gest poety według Bourdieu (zob. tegoż Reguły sztuki, s. 100), z kolei Bataille twierdzi, że przeciwnie - Baudelaire wręcz "nie miał w sobie nic z radykała”, pragnął powrócić do łask, zob. G. Bataille Literatura a zło, przeł. M. Wodzyńska-Walicka, Oficyna Literacka, Kraków 1992, s. 52 . O nowoczesności Norwida w kontekście tez m.in. Benjamina i Bourdieu zob. M. Grabowski Dialektyka przemocy w ofiarniczych tragediach Norwida, "Czytanie Literatury. Łódzkie Studia Literaturoznawcze" 2016. 
w Paryżu. Dlatego od Polaków oczekuje wsparcia dla artystów - w tym dla Olizarowskiego i dla siebie. Świadczą o tym choćby gorzkie wyrzekania na jego brak przy pracy nad Rzeczą o wolności stowa:

- Powinienem był nawet dać możność rodakom, aby mi wdzięcznie pomogli, bo ja nie biorę żołdów od Francji - urzędów od Cesarza i książąt - składek od narodu - pensji od Pa nó w... chciałem, aby mi kurs zapłacono, bo myśliłem, że to będzie pięknie ze strony rodaków względem mnie -

Widząc, że tego uczucia nie ma - chciałem bezpłatnie dla mnie, lecz choć dla Szkoły Batignolskiej. (PW IX, 471)

Wydaje się istotne podkreślanie przez Norwida właśnie gestu odwrócenia się, niezależności od francuskich „żołdów”, prywatnego mecenatu, a nawet od społecznych narodowych składek. To z jednej strony jasne świadectwo buntu wobec systemowych regulacji i nadzoru, proklamowanie niezależności artysty. Z drugiej - jest przecież w tę wypowiedź wpisane wyraźne oczekiwanie zapłaty, która należy się poecie od rodaków, gdyżjego praca jest pracą na rzecz wspólnoty. Zapłata ma być wyrazem uznania, oddania przez słuchaczy wysiłku włożonego przez autora, w tej koncepcji Norwid zamazuje zarobkowy charakter pracy i wraca do idei wymiany. Argumentem na rzecz tego przesunięcia ma być chęć przekazania pieniędzy polskiej szkole w Batignolles. Tak właśnie Norwid chce przekonać, że ważne są dla niego wartości obywatelskie niewspółgrające z „doraźnym interesem i wyzyskiem" (PW VI, 261), jak pisze o Olizarowskim, dla którego jednakowoż występuje o nagrodę za te właśnie wartości. Charakterystyczną dla Norwida oscylację między domaganiem się zapłaty a zrzeczeniem się jej można dostrzec także w dokonanej przez Baudelaire'a prezentacji postawy Delacroix. Pisarz przedstawia go jednocześnie jako geniusza niezależnego od warunków zewnętrznych i artystę zarabiającego na życie. Geniusz pracuje za darmo, nie myśląc o zaroblku, rzemieślnik - przeciwnie, Delacroix bywa jednym i drugim (RE, 393).

W kontekście dotychczasowych rozważań ważny okazuje się Norwidowy projekt Towarzystwa Uszanowania Człowieka z 1875 roku odczytywany w duchu chrześcijańskiego personalizmu jako (antydarwinowska z założenia) próba nadania ram instytucjonalnych działaniom etycznym ${ }^{25}$. Wydawać

25 Zob. np. ks. A. Dunajski Człowiek - „Boga żywego obraz", „Studia Norwidiana” 1983 z. 1, s. 84; R. Zajączkowski Głos prawdy i sumienie: Kościół w pismach Cypriana Norwida, Wydawnictwo UMK, Toruń 2012 S. 35. 
by się mogło, że jest on na antypodach Baudelaire’owskiej krytyki nagród literackich za moralność. Podczas gdy autorowi Paryskiego spleenu wydaje się skrajnie niewłaściwe, a nawet - paradoksalnie - niemoralne nagradzanie za czyny i teksty moralne, Norwid widzi taką konieczność. Co więcej, projektowana instytucja miałaby wedle polskiego poety świadczyć o budzeniu się twórczej mocy Słowian. Jej istotą byłoby wprowadzenie wartości uniwersalnych - promowanie godności każdego człowieka - w warunki zmienne historycznie. Baudelaire pisze: „Co do mnie, nie chciałbym mieć za przyjaciela człowieka, który dostał nagrodę za cnotę; obawiałbym się w nim znaleźć nieubłaganego tyrana" (SzRom, 73). Norwid natomiast proponuje: "Towarzystwo naznaczałoby małe a częste konkursa - dawałoby w nagrodę nie pieniądz, a jednak wartość, aby nie ubliżyćczłowiekowi p i s a r z o wi" (PWX, 54). Chodzi m.in. o konkursowe prace literackie, które wpisywałyby się w ideologię Towarzystwa. W przedmowie do Vade-mecum czy w rozprawce Emancypacja kobiet (PW VI, 652) Norwid woła o moralistów w literaturze polskiej, podkreślając brak w niej „strony obowiązków”. Baudelaire przeciwnie - poddaje krytyce bezpośrednie moralizatorstwo pisarzy jawnie i naiwnie dydaktycznych (Zacne dramaty i powieści) i tworzących w gruncie rzeczy pod publikę, bowiem takie utwory są po prostu poczytne, a "Cnota jest warunkiem sine qua non sukcesu” (SzRom, 72). Jest tu w postawie poetów duża rozbieżność, nie sądzę jednak, by Norwidowi chodziło o promowanie takiego naiwnego i podobającego się publiczności moralizatorstwa, jakie wyśmiewa Baudelaire, który jak Norwid będzie szukał rozwiązań trudnych, świadomie prowokując i wywołując opór czytelnika.

Ważnym aspektem Norwidowego projektu Towarzystwa jest wysiłek stworzenia instytucji własnej, zgodnej z przekonaniami wspólnoty zbudowanej na odrębnych niż narzucone przez władzę podstawach, a zatem instytucji alternatywnej. Jest to jednak wciąż instytucja, która ma za zadanie udzielanie nagród i pochwał, a zatem mamy do czynienia z kolejnym świadectwem oscylacji poety między narzuconymi strukturami a rewoltą, próbą wypracowania autonomicznego pola literackiego. W gruncie rzeczy i Baudelaire, i Norwid buntują się przeciw temu, co jest przytłaczające, nadmiarowe, łatwe i zwracają ku brakom - wedle Baudelaire'a analizującego rynek francuski cnotliwe „zacne dramaty i powieści” należą do dominującej literatury popularnej, Norwid odnoszący się do sytuacji polskich publikacji - stwierdza dojmujący brak literatury podkreślającej kwestie etyczne. 
Można stwierdzić, że i Norwida, i Baudelaire’a cechuje - przy całej niejednoznaczności ich stosunku do pola władzy, którą starałam się wyeksponować ${ }^{26}$ - sprzeciw wobec oficjalnych nagród i instytucji, kontestowanie narzucanych strukturalnie i powszechnie obowiązujących gustów, krótko rzecz ujmując - gesty buntu prowadzące do wyłonienia autonomicznego pola literackiego. Obaj pisarze rzucają wyzwanie ustalonemu porządkowi, dokonując przewrotu symbolicznego. Z tym wyzwaniem wiąże się przekonanie o zamachu na ustalony tryb literackości dokonywanym przez konkretne dzieła traktowane przez samych twórców właśnie jako przełomowe. Parateksty, przedmowy, komentarze zarówno Norwida, jak i Baudelaire'a mają charakter ustanawiający zwrot estetyczny. Obaj wielokrotnie wyrażają przekonanie o wykraczaniu poza oczekiwania współczesnych. Francuski poeta twierdzi, że geniusze zawsze wyprzedzają swoją epokę, i woła: „Czyż nie wychodzi na to, że geniusz jest wyrzutem i zniewagą dla tłumu!" (SzRom, 163), a także: „Narody wydają wielkich ludzi wyłącznie wbrew sobie” (SzR, 397). Norwid wtóruje mu: „[...] wszyscy poeci postępu nieco przynoszący zarówno w rozbracie ze społeczeństwem swym bywali” (PWVI, 458). I dodaje: „Ilekroć coś jest genialne [...] tylekroć woła o zupełny przewrót wszystkiej e s te ty ki" (PW VI, 537). Dlatego obaj z pełną świadomością piszą o niemieszczeniu się w ramach powszechnych gustów epoki. W końcu, co wydaje się konstytutywne dla wykształcenia się pola literackiego, dzieło zaczyna być postrzegane tak, jakby samo w sobie zawierało reguły odczytania, którym każdy twórca może wprowadzać własne nomos. I Norwid, i Baudelaire ustanawiają zatem coś nowego, odmiennego od obowiązującej estetyki, na co nie ma jeszcze języka, dlatego samo musi ten język dla siebie stworzyć. Niewątpliwie

26 Ta niejednoznaczność przekładająca się także na kwestie postępu cywilizacyjnego może skłaniać do określenia ich mianem nie tyle antimodernes, jak chciałby przywołany wcześniej A. Compagnion, ile amodernes, jak czyni J. Acquisto. Zob. J. Acquisto The Fall Out of Redemption. Writing and Thinking Beyond Salvation in Baudelaire, Cioran, Fondane, Agamben and Nancy, Bloomsbury, New York-London 2015. Na temat paradygmatu romantycznego jako wizji świata współistniejącej z kapitalizmem, rewolucją industrialną i dojściem do władzy burżuazji, czyli „nienowoczesnej nowoczesności”, zob. R. Sayre Revolte et mélancolie. Le romantisme à contre-courant de modernité, Payot, Paris 1992. Zob. też: H. Friedrich Struktura nowoczesnej liryki od połowyXIX do połowyXX wieku, przeł. i wstęp E. Feliksiak, PIW, Warszawa 1978, s. 65-67; M. Inglot Rękawiczki Norwida. Między kulturą a cywilizacją, w: tegoż Wyobraźnia poetycka Norwida, PWN, Warszawa 1988; M. Kuziak Norwid i Marks, w: O Norwidzie komparatystycznie, red. M. Siwiec, Wydawnictwo UJ, Kraków 2019, s. 65-67; tegoż Norwid i pejzaż nowoczesności. Wokół Paryża poety, "Studia Norwidiana” 2014 nr 32; S. Rzepczyński Norwid a nowoczesność, w: Romantyzm inowoczesność, red. M. Kuziak, Universitas, Kraków 2009. 
obaj twórcy funkcjonują w fazie krytycznej wyłaniania się pola, co zresztą obaj problematyzują i obaj to pole kształtują - głównie przez te swoje wybory, które idą wbrew temu, co popularne, powszechnie akceptowane, łatwe, przynoszące zyski. O ile jednak działania Baudelaire'a eksponujące autonomię zaczną stawać się normą stosunkowo szybko (bo szybko zyska wielbicieli tej miary co Rimbaud czy Verlaine), Norwida - dopiero po latach, na zasadzie „spóźnionego oddziaływania"27.

\section{Abstract}

\section{Magdalena Siwiec}

JAGIELLONIAN UNIVERSITY (CRACOW)

Norwid, Baudelaire and the Rules of Art

Siwiec discusses Norwid and Baudelaire as writers on the cusp of modernity who are clearly aware of their participation in contemporary social and cultural transformations. Drawing on Pierre Bourdieu's The Rules of Art, a study of the formation of the new literary field in which both poets took part, Siwiec examines the two poets'statements on art's dependency on the laws of the market and on the field of power represented by various institutions. She also exposes the ambivalent - although largely critical - relationship to the transformations of modernity that marks both Norwid and Baudelaire, whom, borrowing Antoine Compagnon's term, we may describe as "antimoderenes".

\section{Keywords}

Cyprian Norwid, Charles Baudelaire, literary field, Pierre Bourdieu, rules of art, modernity

27 Zob. H.R. Jauss Przedmowa do pierwszego niemieckiego wydania..., s. 3. 